\title{
Analysis of Chinese Passive solar building cases
}

\author{
Bei ZHANG
}

Marcel Elswijk,Henk Kaan. European Em-bedding of Passive Houses: PEP-project Re-port 2008

KEYWORD: passive house, building Energy,solar energy,building energy consumption

\begin{abstract}
In recent years, building energy consumption is growing along with the accelerated pace of urbanization. Inside this building energy consumption, conventional heating and ventilation is dominant. In order to save energy consumption, passive house technology has been applied to the Chinese building successfully, so it is particularly important that we study and improve domestic passive buildings. This article contains analysis of three cases about typical passive house , and concluds that their common characteristics and assessment of China's current passive house development prospects.
\end{abstract}

\section{Introduction to passive house}

The concept of passive house building is built on the basis of Germany in the 1980s on low energy buildings. In 1988 Lund University in ,Sweden Professor Adamson and Dr. Pfister Germany first proposed the concept. They think that passive house is not using active heating and air conditioning systems and can maintain a comfortable indoor thermal environment in the building. In China, the passive house is natural ventilation, natural lighting, solar radiation and indoor heating source was non-thermal and other passive means of energy-saving and energy-efficient building envelope technology built from a combination of low-energy housing. This architecture significantly improve the indoor environment in at the same time, it can significantly reduce building energy use, minimize reliance on active mechanical heating and cooling systems.

\section{Development of passive house in china}

Passive houses not only be the inevitable trend of energy efficiency in buildings, and should be the inevitable trend of housing development. In 2007, the Chinese Ministry of Housing and Urban Development of Science and Technology Promotion Center official cooperation with the German Energy Agency. In 2011, the two sides signed the "on building energy efficiency and low-carbon eco-city construction Technical Memorandum of Understanding," pushing "passive house" concept. And in 2014, under the witness of German Chancellor Angela Merkel, Chinese Premier Li Keqiang, the Sino-German eco-park project was formally signed passive house, passive house established China Technology Center, urged industrial restructuring. Recalling passive house road, China formally entered the public eye in the 2010 Shanghai World Expo, "Hamburg House." And now, the "Hamburg House" With the Chinese version of Qinhuangdao "water side" residential district, Urumqi "Happy Castle" Harbin "Chenneng • Creek Tree Garden", the Dalian Golden Pebble Beach "vacation villas" and so on. Up to now, the "passive house" design and construction project 30 places, distributed in Heilongjiang, Hebei, Fujian, Xinjiang, Shandong, Hunan, Jiangsu, Qinghai, Liaoning and other provinces.

\section{Typical cases of passive house}

\subsection{Landsea Brook passive house}

Landsea Group by the German Institute of passive house and the German Energy Agency and other units Brooke passive house construction. In building design, building orientation Brook selection set shape coefficient and envelope design, and so scientifically rigorous energy simulation and optimization analysis. In the heat transfer coefficient of the wall, doors, windows and insulation 
performance whole house airtightness, more stringent requirements than conventional energy-efficient buildings. Zhejiang Province, according to $50 \%$ of the energy efficiency design standards, the heat transfer coefficient of the wall outside the control index was $1.0 \mathrm{~W} /\left(\mathrm{m}^{2} \bullet \mathrm{K}\right)$, and the control indicator Brook is $0.15 \mathrm{~W} /\left(\mathrm{m}^{2} \cdot \mathrm{K}\right)$, the thickness of the insulation material from the usual the $40 \mathrm{~mm}$ optimized for $20 \mathrm{~mm}$; heat transfer coefficient of windows and doors general project control index of $2.5 \sim 3.2 \mathrm{~W} /\left(\mathrm{m}^{2} \cdot \mathrm{K}\right)$, and Brooke indicators of $0.8 \mathrm{~W} /\left(\mathrm{m}^{2} \cdot \mathrm{K}\right)$, commonly used in thermal break aluminum hollow glass products unable to meet these requirements, the project finally adopted $120 \mathrm{~mm}$ thick aluminum clad wood profiles with three double insulating glass. It can be seen in the external structure of the main indicators of heat control architecture, passive house requirements greatly improved.

Brook project in accordance with the German passive house standard design done a very strict and meticulous adiabatic node design. Our summer and cold winter area of building energy-saving design of the building envelope is no detailed break heat treatment requirements, and only mentioned provisions in this regard in energy-saving design standard part of external insulation construction portfolio and the northern cold or in cold areas. For example, the Atlas "exterior insulation and building construction" (10J121) defines the door and window openings, the board and the board shall adopt a balcony parapet under external insulation whole package approach. But breaking thermal design Brook passive house projects more detailed and rigorous, mainly in the balcony off the overall thermal design, paving the way insulation board and a fixed anchor and other measures. And it is this design details, creating a successful passive house building.

\subsection{Qinhuangdao "water side" Residential Quarter}

"In the water side, Area C," the State Department of Housing to carry out Sino-German cooperation passive low-energy housing project demonstration project, built by Qinhuangdao five Hing Group. The main technical characteristics of passive house buildings applications are: high insulation, high airtightness, high comfort; and the application of renewable energy and water rainwater recycling technology, floor insulation and household wall insulation technology, automatic sprinkler systems, high-tech means of the light guide lighting technology.

In the water side residential area in the following areas used technology as an industry model: water recycling, rainwater harvesting, solar energy applications, building energy-saving technologies. Among them, water recycling stations set up in the water, after which the sewage recycling, to achieve "urban recycling urban miscellaneous water quality" standard. Water quality and stability, low price and reliable system operation. Through artificial lake seepage brick, osmotic sunken green, grass brick seepage rainwater harvesting, soil and water balance. The district has 500 cubic meters underground rainwater collection tank for collecting pavement, rooftop rainwater for landscape, green lake and add water. Collected throughout the year, 30,000 cubic meters of rainwater penetration.

Healthy demonstration projects based on the requirements in the selection of building insulation mortar water side as the main energy-saving building maintenance structure and roof insulation materials. Hollow ceramic material enriched particles having low thermal conductivity, thermal insulation effect is remarkable, effective barrier to heat transfer, save energy. There crack the barrier layer material external wall insulation, it can alleviate the problem of cracks and leaks aerated concrete produced.

\subsection{Delta Sun Elementary School}

In 2009, Delta Group donated 10 million yuan built a "Delta Sun Yang Town Primary School", because the original Yang Town Primary School in 2008, "5.12" earthquake severely damaged. The new site is not only the reconstruction of primary seismic level of mandatory requirements, but also uses a passive green design, this passive design, so that school buildings to take advantage of local topography and environmental conditions, to meet the lighting, thermal requirements. The so-called passive energy-saving buildings, mainly refers to the energy does not depend on their own construction equipment, and completely by building its own space in the form, structure, building envelope design and construction of energy-efficient way to achieve the building.

Delta Sun Elementary School building program shows, according to local differences in the 
height of winter and summer sun, school classrooms designed light adjustment programs, the use of sloping roof skylight and pick the eaves outside the classroom windows on the south side of the reflective visor. Summer can block direct light outside the window, the winter sun angle decreases through skylights and reflective visor way to make the room light more evenly.

According sunlight conditions Malcolm region, in the overall planning, the general classrooms and specialized classrooms and administrative offices along the east-west direction part-section Z-shaped offset arranged on the base, which not only helps each classroom can maximize the introduction of natural solar energy for lighting and heating in winter, and can increase the spring and monsoon active role in the classroom for natural ventilation. Teachers and students living quarters arranged in the base area to the south corridor and teaching communication, both within the synthetic Wai open garden with stone benches and green organized so that close contact between the two do not interfere with each other. Architectural form design and use of solar energy are closely related, by the architectural design of the building itself with the means to make the full use of the function and role of solar energy, so as to realize the purpose of energy saving.

\section{Conclusion}

Passive house in the country with the late start, but has broad application prospects. The energy-saving passive houses both residential and large scale reduction in non-renewable energy consumption. This is bound to have a positive and profound impact on the existing natural environment. We should improve our passive house building in continuous learning and improvement, so that energy efficient buildings and green building development in China continue to comprehensive, professional.

\section{References}

[1] Marcel Elswijk, Henk Kaan. European Em-bedding of Passive Houses: PEP-project Re-port 2008

[2]Xiaoyan HUANG.On the Development of Industry and Energy passive house windows[C].2015

[3]Jun CHEN.Green Brook passive house construction applications and the effectiveness of technical analysis[C].2015

[4]Suang LI.Passive energy saving house Technical Analysis and Case Studies[C].2013

[5]Yanlin WU.Architectural Design of Eco Chinese living in northern cold regions[C].2007

[6]http://www.gbwindows.cn/news/201411/7564.html

[7]Yan ZHANG.Malcolm stricken rural primary school sun design[Z].2009 